\title{
Synthesis of Biodiesel from Kesambi Oil using Indigenous Lipase
}

\author{
Mellisa E.S Ledo ${ }^{1 *}$, Merpiseldin Nitsae ${ }^{1}$, and Hartini R.L. Solle ${ }^{1}$ \\ ${ }^{1}$ Faculty of Teacher Training and Education, Artha Wacana Christian University, Kupang, Indonesia
}

\begin{abstract}
Kesambi (Schleichera oleosa L.) is one of ligneous tree that is abundantly found in Timor island, East Nusa Tenggara Province of Indonesia. Kesambi is known as an important component in local smoked meat home industry. Kesambi is also a promising natural source for the production of biodiesel. Application of three lipolytic fungi that is isolated from kesambi seeds and the use kesambi seeds flour as medium for indigenous lipase synthesis (Aspergillus niger M1407 lipase) by Solid-State Fermentation (SSF) showed good result for lipase and biodiesel industry development. This study aimed to characterize biodiesel synthesis using indigenous lipase from kesambi seeds. Experiments were carried out through five stages namely: oil extraction from kesambi seeds, purification of kesambi oil (degumming), extraction of A. niger M1407 lipase, trans-esterification and esterification activity of A. niger M1407 lipase assay and characterization of biodiesel. Biodiesel synthesis using A. niger M1407 lipase through esterification reaction produced biodiesel with an average acid number of 0.33 and $0.40 \mathrm{mg} / \mathrm{g}$, water content $9.52 \%$ and $10.47 \%$ and density $0.7 \mathrm{~g} / \mathrm{mL}$. Biodiesel obtained from kesambi oil has lower acid numbers and densities but higher water content compared to Indonesian National Standard (SNI) value. Optimalization of the biodiesel kesambi oil synthesis could be done through adjusting ethanol and kesambi oil ratio and also by reducing water as a by-product of esterification reaction.
\end{abstract}

Keywords: Kesambi oil, lipase, A. niger M1407, biodiesel characterization

\section{Introduction}

Biodiesel is defined as ethyl ester or methyl esters that is synthesized from vegetable oil or animal fats. Biodiesel is considered as a promising alternative fuels to replace fossil fuels because biodiesel has similar physical properties to petroleum diesel (commonly simplified as diesel). This physical similarity makes biodiesel is able to be directly used on diesel engines without any engine modifications. Another advantages of biodiesel use are its environment friendly effect and renewability because of its biological sources. Types of biological sources for biodiesel raw materials provided by plant and animal oils (Srinivasnaik et al., 2015). Plant oil is a well-known source for biodiesel because of its abundant availability in the nature, but in other hand, plant oils which are used for biodiesel are not edible. Kesambi tree (Schleichera oleosa L.) is a

\footnotetext{
*Corresponding author:

Mellisa E.S Ledo

Faculty of Teacher Training and Education, Artha Wacana Christian University

Jl. Adi Sucipto No. 147, Oesapa, Kupang, Indonesia E-mail: mellissaerlynsledo@gmail.com
}

common local tree in East Nusa Tenggara. Kesambi that is widely used in smoked meat home industry in Kupang, East Nusa Tenggara is also promising to be used natural source of biodiesel. Oil from kesambi is also known containing cyanide acid (Sudrajat et al., 2010).

Biodiesel synthesis can be carried out through esterification or trans-esterification reactions using plant oil as the substrate which will react with short-chain alcohol and uses a catalyst to accelerate the reaction. There are two types of catalysts used in biodiesel synthesis, such as chemical catalysts and biological catalysts (enzymes). Biological catalysts or enzymes are considered as the representation of a promising strategy in supporting the concept of "green chemistry". Lipase is an enzyme or biological catalyst that is commonly used in biodiesel synthesis. Some lipolytic fungi are known to produce extracellular lipases. The finding from Sele and Ledo in 2013 showed Aspergillus niger, Aspergillus flavus and Penicillium sp isolated from kesambi seeds have a lipotytic potency. Lipase production using kesambi seed flour as a medium through SolidState Fermentation (SSF) using Aspergillus 
niger $65 \mathrm{i} 6$ that isolated from Jatropha seeds showed the production of crude lipase extract with lipase activity $192.30 \mathrm{U} / \mathrm{mL}$ (Ledo and Sabuna, 2015).

Crude extract activity of Aspergillus niger M1407 and Penicillium sp lipases in biodiesel synthesis with oleic acid substrate were $137.5 \mathrm{U} / \mathrm{mL}$ and $50 \mathrm{U} / \mathrm{mL}$ (Ledo et al., 2016). Synthesis of biodiesel from kesambi oil (S. oleosa L.) using heterogeneous base catalysts from carbide waste has been carried out by Syarif et al., (2016). Thus, this research was conducted on biodiesel synthesis from kesambi oil using A. niger M1407 lipase as an effort to develop environmental friendly biodiesel industry.

\section{Materials and Methods}

Kesambi seeds were collected from areas near Artha Wacana Christian University, Kupang, East Nusa Tenggara. This experiment was carried out through five stages as follows:

\section{Extraction of kesambi oil}

Five kilograms of high grade mass of kesambi seed (oil cake) were grinded with blender or mortar. Grinded material would be then being pressed until oil is yielded. Oil was then filtered to collect kesambi oil which is ready to be used for biodiesel production.

\section{Purification of kesambi oil (degumming)}

A total of $150 \mathrm{ml}$ of kesambi oil was underwent purification through three stages, namely degumming, neutralization and bleaching. Degumming process was performed using warm distilled water (60 ${ }^{\circ}$ C) $20 \%$ v/v. Neutralization step was carried out using $2.7 \mathrm{~mL}$ of $4.12 \mathrm{M} \mathrm{NaOH}$. Bleaching was done using zeolite $5 \% \mathrm{w} / \mathrm{v}$.

\section{Extraction of A. niger M1407 lipase}

Extraction of $A$. niger M1407 lipase was performed using method referred to Gutarra et al. (2009). Fermented kesambi seed flour was weighed, then added with $0.1 \mathrm{M}$ phosphate buffer $\mathrm{pH} 8(5 \mathrm{~mL} / \mathrm{g}$ substrate $)$ and homogenized on shaker at room temperature with speed $100 \mathrm{rpm}$ for $20 \mathrm{~min}$. Mixture was then filtered to separate solid fermentation medium and liquid enzyme, separation was carried out using centrifuges with speed 3000 rpm for $30 \mathrm{~min}$, Supernatant (crude extract lipase A. niger M1407) was collected and stored at temperature of $-18^{\circ} \mathrm{C}$.

\section{Trans-esterification and esterification Activity of A. niger M1407 lipase Assay)}

$A$. niger M1407 lipase was tested by the presence of alkyl esters from pure kesambi oil and crude kesambi oil with 5 drops of $1 \%$ phenolphthalein as indicator and titrating using $0.2 \mathrm{M} \mathrm{NaOH}$ solution. Titration was stopped after the mixture change color onto pink. Lipase activity was determined from the volume of $\mathrm{NaOH}$ for sample titration minus the volume of $\mathrm{NaOH}$ for control titration. Every $1 \mathrm{ml}$ of $50 \mathrm{mM} \mathrm{NaOH}$ is equivalent to 100 units of lipase activity. The unit of enzyme activity is calculated by the formula:

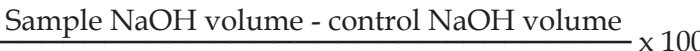 enzyme volume}

\section{Characterization of biodiesel}

Biodiesel characterization was performed by matching biodiesel parameters obtained in this research to the standard value provided by Indonesian National Standard (SNI) No. 7182: 2015. Compared parameters consists of acid numbers, density and water content.

\section{Result}

Trans-esterification and Esterification activity of A. niger M1407 lipase in biodiesel Synthesis

Crude kesambi oil used in this study was obtained from kesambi seeds which were then used for biodiesel synthesis through trans-esterification reactions using $A$. niger M1407 lipase. Kesambi oil is composed of several fatty acids such as myristic acid, palmitic acid, stearate acid, arachidic acid, oleic acid and linoleic acid. Among these fatty acids, arachidic acid and oleic acid are the dominant constituents in kesambi seed oil (Seran, 2011). After the oil is extracted from kesambi seeds, it cannot be used directly for fuel. The oil must be processed through 
Table.1. A. niger M1407 lipase activity in the synthesis of biodiesel (methyl ester and ethyl ester) from kesambi oil.

\begin{tabular}{cclc}
\hline No & \multicolumn{1}{c}{ Substrate } & \multicolumn{1}{c}{ Solvent } & A. niger M1407 Lipase Activity (U/mL) \\
\hline 1 & Crude kesambi oil & methanol and isooctana & 16 \\
& & ethanol and isooctana & 75,2 \\
2 & Pure kesambi oil & methanol and isooctana & 1920 \\
& (degumming) & ethanol dan isooctana & 800 \\
\hline
\end{tabular}
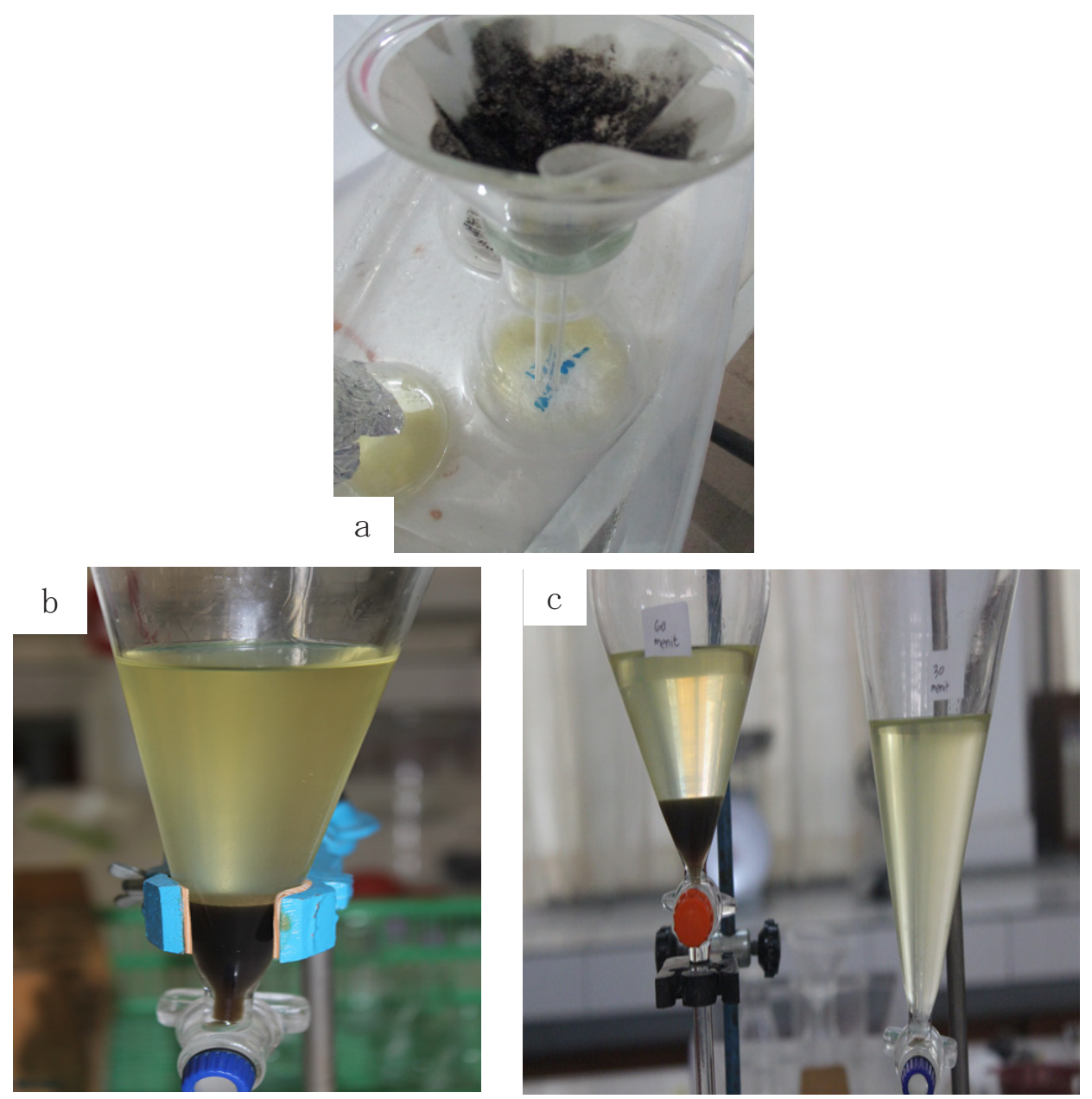

Figure 1. Representative picture for extraction of A. niger M1407 lipase (A) and its use in biodiesel synthesis from kesambi oil (B and C).

esterification or trans-esterification stage or a combination of both (esterification-transesterification) to form methyl or ethyl ester. Results for A. niger M1407 lipase activity in the synthesis of methyl ester and ethyl ester from kesambi oil through the transesterification and esterification reaction stages is shown in Table 1. Representative picture for extraction of A. niger M1407 lipase and its use in biodiesel synthesis from kesambi oil is shown in Figure 1.
A. niger M1407 lipase activity in catalyzing crude kesambi oil during transesterification reaction for the synthesis of biodiesel showed relatively low activity. Interestingly, there was an increase in $A$. niger M1407 lipase activity when synthesizing biodiesel through esterification reaction using pure kesambi oil (result of the degumming process). It was observed that highest lipase activity was reached by esterification using methanol solvents. 


\section{Quality of Kesambi Oil-based Biodiesel}

Synthesis of biodiesel (ethyl ester) through esterification reaction after purification of kesambi oil showed high activity, therefore further step was done by adjusting variation of esterification time (30 and $60 \mathrm{~min}$ ). Determination of the quality of biodiesel was performed by calculating acid number, water content and density. Characterization of ethyl ester from kesambi oil are listed in Table 2.

\section{Discussion}

Trans-esterification and Esterification activity of A. niger M1407 lipase in biodiesel Synthesis

The use of crude kesambi oil as a substrate for the synthesis of biodiesel in the presence of A. niger M1407 lipase caused a decrease in enzyme activity, diversity of fatty acids types in crude kesambi seed oil and the presence of other impurities (proteins, gums etc.). All of these factors can be inhibit the work of the lipase enzyme A. niger M1407. Oil with low free fatty acid content requires only one stage of trans-esterification but oils with high free fatty acid content need several reaction steps in the shake of efficient process (Canakci and Gerpen, 1999).

Factors affecting trans-esterification consist of internal factors and external factors. Internal factors is oil condition or quality which are shown by its water content, free fatty acid content and solute content. External factors consists of temperature, reaction time, stirring speed, type and concentration of catalyst concentration, and of molar ratio of solvent to the oil. In trans-esterification reaction, base catalyst such as $\mathrm{NaOH}$ and $\mathrm{KOH}$ is commonly used. The advantages of using $\mathrm{NaOH}$ as catalyst in the trans-esterification reaction is its easy-solubility in methanol, then reaction between methanol and triglyceride takes place faster (Ma and Hanna, 1999).
The type of alcohol that is always used in the trans-esterification process is methanol and ethanol. Both alcohols has transparent color like water, volatile, flammable and easily mixed with water. Methanol is the most preferred in the manufacture of biodiesel as methanol $\left(\mathrm{CH}_{3} \mathrm{OH}\right)$ is easier to react and more stable compared to ethanol $\left(\mathrm{C}_{2} \mathrm{H}_{5} \mathrm{OH}\right)$. This phenomenon is supported by the number of carbon bound own by each alcohol. Methanol has one carbon bonds (ethanol has two carbon bonds) which making it easier to obtain the separation of glycerol compared to ethanol. The disadvantages of using methanol related to its toxicity and could be harmful to skin, eyes, lungs and digestive organs. Methanol also can damage plastic and rubber made of coal. On the other hand, ethanol is more secure, non-toxic and mainly made of agricultural products. Although lipase activity was higher when using methanol solvent for biodiesel characterization, for a safety purpose, ethanol was chosen as solvent for esterification of kesambi oil as our next stage of this study. Thus, although the activity of $A$. niger M1407 lipase in catalyzing trans-esterification reaction in kesambi oil biodiesel was relatively low, optimization can be done through adjusting substrateenzymes ratio, purification of kesambi oil before use on the trans-esterification reaction, temperature variation, $\mathrm{pH}$ variation and Vmax assay. Degumming step of kesambi oil before being used on the trans-esterification reaction with $A$. niger M1407 lipase showed high activity, but foam formation due to the saponification reaction between kesambi oil and $\mathrm{NaOH}$ in this degumming stage caused difficulties in the separation of final product. Trans-esterification reaction catalyzed by lipase enzyme increases quantity and quality of plant oil conversion to biodiesel. These quality parameters includes no saponification (no foam formation), high conversion

Table 2. Characterization of biodiesel (ethyl ester) from kesambi oil compared to SNI

\begin{tabular}{clccc}
\hline No & \multicolumn{1}{c}{ Sample } & $\begin{array}{c}\text { Acid Number } \\
(\mathbf{m g} / \mathbf{g})\end{array}$ & $\begin{array}{c}\text { Water Content } \\
\mathbf{( \% )}\end{array}$ & $\begin{array}{c}\text { Density } \\
\left(\mathbf{k g} / \mathbf{m}^{\mathbf{3}}\right)\end{array}$ \\
\hline $\mathbf{1}$ & Biodiesel (esterification 30 minute) & 0,33 & 9,52 & 700 \\
$\mathbf{2}$ & Biodiesel (esterification 60 minute) & 0,40 & 10,47 & 700 \\
$\mathbf{3}$ & SNI & 0,5 & 0,05 & $850-890$ \\
\hline
\end{tabular}


product, easy to be purified product, and glycerol that is formed is easy to be separated (Fukuda et al., 2001; Hasan et al., 2006)

\section{Quality of Kesambi Oil-based Biodiesel}

Biodiesel acid numbers obtained in this study was below the value of SNI biodiesel. A high acid content in fuel oil will adversely affect the performance of engine combustion engine. The presence of acid will cause corrosion in the engine, thus inhibiting the combustion process. Acid number would then become one of the important factors in determining biodiesel process. Decreasing levels of free fatty acids from oil after underwent an esterification process occurs because in the esterification process free fatty acids in oil are mostly converted to methyl or ethyl ester (Bajpai et al., 2006)

Biodiesel density in this study was below SNI range. Parameters such as density or specific gravity of oil or biodiesel are influenced by the chain length of fatty acids, unsaturation and ambient temperature (Formo, 1979). The presence of compounds such as soap, residual reagents, and resins in biodiesel as a result of incomplete separation is the main cause of the high density value of biodiesel.

The water content of biodiesel in this study is quite high $(9.52 \%$ and $10.47 \%)$ surpassing SNI value for biodiesel water content $(0.05 \%)$. The presence of water as a side product from lipase esterification reaction is inevitable, so it is necessary to do a process to separate biodiesel and water for better results. Optimization of processes, both internally and externally, to increase lipase activity of $A$. niger M1407 in catalyzing the esterification reaction of ethyl ester and separation of water as a by-product can be an effort to improve the quality of biodiesel produced from kesambi oil esterification.

\section{Conclusion}

Synthesized biodiesel from kesambi oil in this research was shown to have lower acid numbers and densities but higher water content compared to Indonesian National standard (SNI, No. 7182: 2015). Optimalization of the biodiesel synthesis from kesambi oil could be done through adjusting ethanol-kesambi oil ratio and reducing water as a by-product of esterification reaction.

\section{Acknowledgement}

This research was funded by Faculty of Teacher Training and Education, Artha Wacana Christian University, Kupang in 2019. We would like to express our gratefulness for this research financial support.

\section{References}

Bachli, Y. (2007). Plant Kesambi and Farming Flea for Welfare. Bulletin of Ministry of Agriculture, 1 (3).

Bajpai, D \& V. K. Tyagi. (2006). Biodiesel: Source, Production, Composition Properties and Its Benefits. Jurnal Oleo Science, 55: 487-502.

Canakci, M \& Van Gerpen, J. (1999). Biodiesel production via acid catalysis. Transaction of the ASAE, 42: 1203-1210.

Champe C. P., Harvey, A. R., Ferrier, R \& Denise. (2010). Biochemistry Picture Review Edition 3. Jakarta: EGC.

Demirbas, A. (2009). Biodiesel from Waste Cooking Oil Via Base-Catalytic and Super Critical transesterification. Journal of Energy Conversion and Management, 50: 923-927.

Dosanjh, N.S\& Kaur,J. (2002). Immobilization, Stability, and Esterification Studies of A. Lipase from Bacillus sp. Journal Biotechnology and Applied Biochemistry, 36: 7-12, Punjab University, Chandigarh.

Formo M. W. (1979). Physical Properties of Fats and Fatty Acids. In The Bailey's Industrial Oil and Fat Products. Vol 1,4 ${ }^{\text {th }}$ Ed. John Wiley and Sons, New York.

Fukuda, H., Kondo, A., \& Noda, H. (2001). Biodiesel Fuel Production by Transesterification Oil. Journal Bioscience and Bioengineering, 92: 405-416.

Hasan, F., Shah, A. A., \& Hameed, A. (2006). Industrial Aplication of Microbial Lipases, Microbial research Laboratory. Department of Biological, Quid-i-Azam University, Islamabad Pakistan

Haryanto, B. (2002). Alternative Biodiesel Fuels: Introduction. Faculty of 
Ledo et al.

Engineering, Chemical Engineering Department, University of North Sumatra, Medan.

Ledo, M. E. S., Dima, Y. R., \& Nope, J. V. V. (2016). Lipolytic Activity Aspergillus niger and Penicillium sp. Indigenous isolated from seeds Kesambi (Schleichera oleosa). Proceedings of the National Seminar Science and Techniques University of Nusa Cendana, Kupang.

Ledo, M. E. S \& Sabuna, A. C. (2015). Production Lipase by Aspergillus niger with Utilization of seeds Kesambi (Schleichera oleosa) as Medium Through Solid State Fermentation. Journal of Biotropikal Science, Vo. 12, no. 1, April 2015, University of Nusa Cendana, Kupang.

Sana, N. K., Hosin., Haque., \& Ranajit, K.S. (2004). Identification, Purification, and Characterization of Lipase from Germinating Oil Seeds (Brassica napus L.). Bangladesh: University of Rajsahi.

Saxena, R. K., Ghosh, P. K., Gupta, R., Davidson, S., Bradoo, S., \& Gulati,R. (1999). Microbial Lipases Potential Biocatalyst for the Future Industry. Curr Sci. 77: 101-115.

Saxena, R. K., Davidson, W. S., \& Sheoran, A. (2003). Purification and Characterization of an Alkaline Thermostable Lipase from Aspergillus carneus. Process Biochemistry, 39 : 239-247.

Sele, Y \& Ledo, M. (2013). Isolation and Identification of lipolytic fungi from kesambi seeds (Schleichera oleosa). Biotropical Journal of Science. University of Nusa Cendana, Kupang.

Seran, Y. K. (2011). Isolation, Characteristics, and Identification of the Main Fatty Acids of Kesambi Seed Oil (Schleichera oleosa (lour.). Thesis (Bachelor), Malang State University, Malang.

Srinivasnaik, M., Sudhakar., \& Naik, B. (2015). Biodiesel as Alternative Green Fuel to Internal Combustion Diesel Engines. Journal of Industrial Engineering and Management Sciensce, 5 (2) : 63-66.

Sudrajat, R., Pawoko, E., Hendra, D., \& Setiawan, D. (2010). Making Biodiesel from Kesambi Seeds (Schleichera oleosa
Sciscitatio, Vol. 1, No. 1, Januari 2020

L.). Journal of Forest Products Research, 28 (4): 358-379. 